\title{
Functional annotation of human cytomegalovirus gene products: an update
}

\author{
Ellen Van Damme and Marnix Van Loock* \\ Janssen Infectious Diseases BVBA, Therapeutic Area of Infectious Diseases, Beerse, Belgium
}

\section{Edited by:}

Michael Nevels, University of

Regensburg, Germany

Reviewed by:

Jens Von Einem, UIm University Hospital, Germany

Klaus Früh, Oregon Health and

Science University, USA

Michael Nevels, University of

Regensburg, Germany

Matthew Reeves, University College

London, UK

\section{*Correspondence:}

Marnix Van Loock, Janssen

Infectious Diseases BVBA,

Therapeutic Area of Infectious

Diseases, Turnhoutseweg 30, 2340

Beerse, Belgium

e-mail:mvloock@its.jnj.com
Human cytomegalovirus is an opportunistic double-stranded DNA virus with one of the largest viral genomes known. The $235 \mathrm{kB}$ genome is divided in a unique long (UL) and a unique short (US) region which are flanked by terminal and internal repeats. The expression of HCMV genes is highly complex and involves the production of protein coding transcripts, polyadenylated long non-coding RNAs, polyadenylated anti-sense transcripts and a variety of non-polyadenylated RNAs such as microRNAs. Although the function of many of these transcripts is unknown, they are suggested to play a direct or regulatory role in the delicately orchestrated processes that ensure HCMV replication and life-long persistence. This review focuses on annotating the complete viral genome based on three sources of information. First, previous reviews were used as a template for the functional keywords to ensure continuity; second, the Uniprot database was used to further enrich the functional database; and finally, the literature was manually curated for novel functions of HCMV gene products. Novel discoveries were discussed in light of the viral life cycle. This functional annotation highlights still poorly understood regions of the genome but more importantly it can give insight in functional clusters and/or may be helpful in the analysis of future transcriptomics and proteomics studies.

\section{INTRODUCTION}

Human cytomegalovirus (HCMV) is a common opportunistic pathogen with a worldwide prevalence of $45-100 \%$ depending on age, location, gender and socio-economic status (Cannon et al., 2010). Initial infection is followed by life-long persistence characterized by periodical reactivation episodes. Whereas in healthy individuals, initial infection and reactivation of the virus usually does not result in morbidity (Boeckh and Geballe, 2011); the virus can cause devastating complications in neonates and immunecompromised patients such as birth defects, systemic failure and rejection of the transplanted organ (Griffiths, 2006; Pass et al., 2006; Kenneson and Cannon, 2007; Crough and Khanna, 2009).

HCMV is a double-stranded DNA virus and with a genome length of $235 \mathrm{kB}$ it has the largest genome of the Herpesvirus family. The genome contains a unique long (UL) and a unique short (US) region each flanked by terminal (TRL and TRS), and internal (IRL and IRS) inverted repeats (Murphy and Shenk, 2008). The genetic map of clinical strain Merlin was thought to contain 165 protein coding genes (Dolan et al., 2004). A later study identified an additional four new protein coding transcripts, i.e., RL8A, RL9A, UL150A, and US33A. In this study, it had already been suggested that more ORFs could exist which code for small proteins (Gatherer et al., 2011). A recent study confirmed this hypothesis and revealed a previously unprecedented complexity of HCMV gene expression when they identified an additional 604 protein coding ORFs, most of which were very short and located upstream of longer ORFs (Stern-Ginossar et al., 2012). In addition to protein coding genes, HCMV also produces polyadenylated non-coding RNAs. A first type of non-coding
RNAs are the abundantly produced long non-coding RNA2.7, RNA1.2, RNA4.9, and RNA5.0 which do not overlap with protein coding regions. Secondly, non-coding RNAs are produced antisense of protein coding regions (Zhang et al., 2007; Gatherer et al., 2011). Finally, HCMV also codes for non-poly-adenylated RNAs, e.g., micro-RNAs which play a regulatory role (Dhuruvasan et al., 2011).

Expression of HCMV genes in permissive cell types proceeds in a temporal cascade initiated with the expression of immediateearly genes followed by the production of early, early-late and late transcripts (Wathen and Stinski, 1982; Stinski et al., 1983; Stenberg et al., 1985). In cell types that support the establishment of latency, such as $\mathrm{CD} 14^{+}$monocytes and $\mathrm{CD} 34^{+}$progenitor cells, an alternative transcription program is followed in which a limited set of transcripts sustains the latent state of the virus (Bevan et al., 1991; Beisser et al., 2001; Goodrum et al., 2002; Jenkins et al., 2004; Cheung et al., 2006; Goodrum et al., 2007; Reeves and Sinclair, 2009; Poole et al., 2013).

In a large scale study Dunn et al. (2003) identified 45 core gene products of which $78 \%$ are essential for growth in fibroblasts and appear to be conserved amongst all Herpesviruses, the remaining essential proteins are either HCMV or $\beta$-Herpesvirus specific. Equally interesting was the observation of 117 proteins which were dispensable for growth in fibroblasts. In addition, several genes appeared to be involved in viral growth suppression. UL9, UL20a, UL23, or US30 gene deletion resulted in enhanced growth in fibroblasts whereas similar observations were done for the UL10 and UL16 gene in endothelial cells and for the US16 and US19 gene in HMVECs. Although this appears 
counterproductive for viral replication, it was suggested that they may be part of a mechanism to prevent massive cellular damage and host death and/or to be involved in suppressing lytic infections to facilitate the establishment of latency. Largely confirming the gene deletion analysis of Dunn et al. (2003); Yu et al. (2003) performed random transposon mutations in HCMV and identified 41 essential, 88 non-essential, and 27 augmenting ORFs (Yu et al., 2003). However, at the time, the function of many of these genes was still unknown. Several of these gene products were later on functionally annotated by Mocarski (2007) in a comparative study between HCMV, HHV-6 and HHV-7 (Mocarski, 2007). This overview of HCMV gene functions dates from 2007 and in the meantime numerous gene products were investigated since. In addition, some gene products were implicated in new viral processes. For example, UL32 (pp150) was described to be involved in maturation during the lytic cycle (Aucoin et al., 2006). However, recently, a role for this gene product was also delineated in gene expression regulation and modulation of the host cell cycle (Bogdanow et al., 2013). In addition, numerous genes with a previously unknown function were investigated and are now attributed with a role in the viral life cycle. In this review, we provide an updated, non-exhaustive functional annotation of the HCMV genome based on curation of the literature, previous reviews and the Uniprot database (Supplementary Table 1).

\section{METHODOLOGY}

The functional annotation presented here is based on three different sources of information. First, the functional keywords published in Dunn et al. (2003) and Mocarski (2007) were included for each gene. Second, the ontology "biological process" found in Uniprot (Apweiler et al., 2004; Boutet et al., 2007) for each gene was used, even predicted annotations. If this information was not available, the ontology "cellular component" was used, the latter was intended to provide additional information on gene products, e.g., on the presence of a certain protein in the tegument or virion. Only reviewed Uniprot entries were included in the data presented here and, unless otherwise stated, the entry for the clinical strain Merlin was used. Finally, literature was manually searched using Pubmed (http://www.ncbi.nlm.nih.gov/pubmed, searches performed in December 2013) to fill in functional annotations discovered since the last overview in 2007. For each gene, the following searches were performed in Pubmed: "gene name and cytomegalovirus" and "gene name and HCMV." Functional annotations were based on the information found in the title and/or abstract of retrieved publications. Each unique function was summarized in a keyword as others have done before (Dunn et al., 2003; Mocarski, 2007). Additionally, the time-kinetics of each gene product and whether or not the ORF is dispensable for growth in fibroblasts is provided based on a gene deletion study by Dunn et al. (2003); and a study using random transposon mutations in HCMV genes by Yu et al. (2003).

In addition to previous reviews (Dunn et al., 2003; Mocarski, 2007), we also included functional annotations for RL5A, RL8A, RL9A, UL1, UL37, UL81ast, UL118, UL131A, UL145 and all four IncRNAs. Recently, several genes (RL3, RL5, RL7, RL8, UL41, UL49.5, UL58, UL60, UL63, UL66, UL106, UL107, UL125,
UL126, UL131, UL137, UL143, UL151, US4, US5, and US35) were shown not to code for proteins, these genes were omitted from this functional annotation (Davison et al., 2013).

\section{FUNCTIONAL ANNOTATION OF HCMV GENES DURING THE LYTIC VIRAL LIFE CYCLE}

Since the publications of Dunn et al. (2003) and Mocarski (2007), the functions of several genes have been unraveled. The aim of the section below is to review these novel functions in the context of the viral life cycle.

HCMV can infect a variety of cell types including, but not limited to, fibroblasts, endothelial cells, epithelial cells and cells of the myeloid lineage (Sinzger et al., 1999; Arrode and Davrinche, 2003; Durose et al., 2012; O'Connor and Shenk, 2012; Bayer et al., 2013). Depending on the cell type, the virus enters the cell by membrane fusion or by $\mathrm{pH}$-mediated endocytosis. The former process is found in fibroblasts and mediated by the $\mathrm{gH} / \mathrm{gL} / \mathrm{gO}$ protein complex; the latter means of entry is typical for epithelial and endothelial cells and requires the gH/gL/UL128/UL130/UL131 pentameric complex (Wang and Shenk, 2005; Ryckman et al., 2008). Different proteins have been attributed a role in cell tropism or cell-specific replication before (Dunn et al., 2003; Mocarski, 2007). Recently, it was shown that the UL128-UL131A cluster rapidly mutates in fibroblasts and UL128 gene mutations appear to serve as a means to optimize viral replication in fibroblasts (Stanton et al., 2010). Based on mutational studies, UL131A was also found to be important for endothelial tropism as part of the pentameric entry complex (Schuessler et al., 2012). Besides the UL128-UL131 locus, US16 and UL78 (Mocarski, 2007; Bronzini et al., 2012; O'Connor and Shenk, 2012) and possibly RL4-RL5, RL13, UL1, UL39, UL83, UL109, UL110, UL111A, UL132, UL148, and US22 are involved in epithelial tropism (Stanton et al., 2010; Womack, 2011; Shikhagaie et al., 2012).

Following entry, a temporal cascade starts resulting in expression of immediate early (IE), early (E) and late (L) HCMV proteins (Supplementary Table 1). There is a general consensus that the production of IE1 and IE2, assisted by several additional proteins, initiates the viral replication (Colberg-Poley, 1996). In addition, US24 was suggested to play an important role in the progression of the cascade as the replication cycle of US24deficient viruses is blocked after the viral DNA reaches the nucleus and before immediate-early mRNAs are transcribed (Feng et al., 2006).

During the progression of HCMV replication, the virus tightly modulates its own gene expression at various times during the temporal cascade. A good example of a complex regulatory mechanism which includes both viral and cellular factors is the control of the major immediate-early promotor (MIEP). The activity or repression of the MIEP is dependent on its association with active or inactive chromatin and thus with acetylated and demethylated histones or deacetylated and methylated histones, respectively (Reeves, 2011). Furthermore, the MIEP contains motifs for the binding of cellular and viral activating (e.g., CREB, NFkB, AP1) and/or repressive transcription factors (e.g., SBP, modulator recognition factor, PDX1, YY1, methylated DNA-binding protein, GFI-1, ERF) (Meier and Stinski, 1996; Stinski and Meier, 2007). 
Two additional viral products, i.e., pp71 (UL82), a tegument protein; and pp65 (UL83), mostly known for its properties as an immune modulator, were found to transactivate or regulate the MIEP (Homer et al., 1999; Hofmann et al., 2002; Cristea et al., 2010; Arcangeletti et al., 2011; Tomtishen, 2012). Other proteins such as UL97, products of the UL28-UL29 locus and US28 mediate the MIEP via cellular transcription factors (i.e., US28), via HDACs (UL97 and UL28-UL29) or via modulation of the host (UL32/pp150) (Mitchell et al., 2009; Wen et al., 2009; Terhune et al., 2010; Bigley et al., 2013; Bogdanow et al., 2013). Also US3 gene expression is tightly regulated. The US3 gene is an auxillary IE gene which retains the MHC-I heavy chain proteins in the ER and works as an immunomodulator. The US3 gene is activated by pp71, IE1, IE2 and TRS1 while repression is mediated by UL34 (Biegalke, 1999; Mocarski, 2007). In addition, UL37.1/UL38 and UL84 inhibited IE1 and IE2-mediated US3 expression (Biegalke, 1999). Later in the viral life cycle during late gene expression, UL79, UL87 UL91, UL92, and UL95 were recently found to be involved in the accumulation of late genes (Isomura et al., 2011; Perng et al., 2011; Omoto and Mocarski, 2013, 2014).

During late stages of infection, the virus ensures that viral DNA replication is established (Tandon and Mocarski, 2012). Recently, UL36, UL49, UL80, UL100, UL117, and TRS1 have been attributed an essential role in DNA replication (Smith and Pari, 1995a; Krzyzaniak et al., 2007; Nguyen et al., 2008; Qian et al., 2008; Marshall et al., 2009; Zhang et al., 2010; Wang et al., 2013a) while the importance of UL112-UL113 and UL84 during DNA replication was further delineated (Colletti et al., 2007; Gao and Pari, 2009; Kagele et al., 2009; Kim and Ahn, 2010; Strang et al., 2012). In addition, UL76 was found to modulate the expression of the essential protein UL77 possibly as part of a mechanism to modulate UL77 levels required for efficient viral replication (Dunn et al., 2003; Isomura et al., 2010). Interestingly, UL55 and UL76 were identified to inhibit DNA replication suggesting that these viral factors are likely key proteins to fine-tune the replication process (Wang et al., 2004; Xiaofei et al., 2012).

Upon the creation of new genomes, the DNA is packaged in newly formed capsids. Based on predictions, UL80.5 and UL93 may be involved in capsid formation (Apweiler et al., 2004; Loveland et al., 2007) whilst the role of UL51 in packaging of the genome was confirmed. Interestingly, also the neighboring gene UL52 was attributed a role in genome packaging (Mocarski, 2007; Borst et al., 2008, 2013). After the encapsidation of the DNA, the immature virion is transported from the nucleus to the cytoplasm to undergo maturation processes such as primary and secondary envelopment (Tandon and Mocarski, 2012). Recently, the protein products of the UL133-UL138 region were found to be important for the formation of the cytoplasmic assembly complex, more specifically in endothelial cells (Bughio et al., 2013). Further, UL96 has been found to stabilize pp150-associated nucleocapsids during translocation from the nucleus to the cytoplasm (Tandon and Mocarski, 2011) and UL32/pp150 preserves the integrity of the immature virion during maturation events. Also, UL32/pp150 enables the proper assemby of the tegument layers during the final phase of maturation (Aucoin et al., 2006). Additional mutation or deletion studies showed crucial roles for UL71, UL74, UL94, and US17 in the final stages of secondary envelopment (Jiang et al., 2008; Schauflinger et al., 2011; Meissner et al., 2012; Phillips and Bresnahan, 2012; Gurczynski et al., 2014). US28 was predicted, based on homology, to also have a role in maturation; however, further research will need to validate this hypothesis. UL89 suppression using shRNA leads to a defect in viral particle formation although a specific mechanism has not been identified (Thoma and Bogner, 2010). Finally, UL74, US17, and UL103 were attributed a role in the egress of newly formed virions (Jiang et al., 2008; Thoma and Bogner, 2010; Ahlqvist and Mocarski, 2011).

Throughout the life cycle, viral proteins which regulate cellular trafficking are integral in the viral replication cycle. Upon membrane fusion, the capsid is released in the cytoplasm and transported to the nuclear pore to release the viral DNA in the nucleus. After replication, new capsids are transported to the cytoplasm to acquire a host-derived membrane before virion release (Fulcher and Jans, 2011; Henaff et al., 2012). As part of this process, a role in directing capsids to the final sites of envelopment has been proposed for UL32/pp150 (Kalejta, 2008). Whilst UL52 has been proposed to be involved in capsid transport, UL50 and UL53 have been confirmed as factors responsible for nuclear egress for which they recruit UL97 (Mocarski, 2007; Sharma et al., 2014).

The composition of the virion depends on the nature of the starting cell line and methods of culturing and purification (Gibson, 2008b). However, it consists of highly conserved proteins categorized into virion capsid components, tegument and envelope proteins (Dunn et al., 2003; Mocarski, 2007; Gibson, 2008a; Kalejta, 2008; Tomtishen, 2012). Several new virion proteins have been identified recently, some still with an unknown function. The UL1 protein, a late protein, is now determined to be an envelope protein and was found at assembly sites in the presence of other viral structural proteins (Shikhagaie et al., 2012). Analysis of the UL1 sequence positions the gene in the RL11 family which also includes RL5A, RL6, RL11, RL12, RL13, and UL4-UL14 genes (Mocarski, 2007; Shikhagaie et al., 2012). Interestingly, but not surprising, as the UL1 gene is thought to originate from a RL11-RL13 gene duplication, is that the RL13 gene product has also been described as a new glycosylated envelope protein (Stanton et al., 2010). Although not experimentally verified, Uniprot suggests (prediction based on similarity) that also RL12 and UL29 may be a part of the virion (Apweiler et al., 2004). Finally UL26 has been attributed a role in virion stability (Kalejta, 2008).

The progression of the viral life cycle also depends on the capability of the virus to modulate host cell processes such as cellular gene expression and apoptosis to its advantage. Recently, US27 was identified as a modulator of cellular gene expression (Arnolds et al., 2013) whilst UL28-UL29, UL38, UL79 and RNA2.7 were found to control apoptosis (Reeves et al., 2007; Terhune et al., 2007; Moorman et al., 2008; Siew et al., 2009; Xuan et al., 2009; Qian et al., 2011; Fliss and Brune, 2012; Costa et al., 2013; Savaryn et al., 2013).

\section{NOVEL FUNCTIONAL ANNOTATIONS OF HCMV GENES EXPRESSED DURING LATENCY}

As all herpesviruses, HCMV establishes latency but HCMV specifically resides in myeloid cells such as $\mathrm{CD} 34^{+}$progenitor 
cells and $\mathrm{CD}_{14}{ }^{+}$monocytes (Taylor-Wiedeman et al., 1991; Mendelson et al., 1996; Sindre et al., 1996; Bolovan-Fritts et al., 1999). Upon differentiation stimuli, latent virus can reactivate and re-enter the lytic life cycle resulting in the production of infectious virions (Soderberg-Naucler et al., 1997; Zhuravskaya et al., 1997; Hahn et al., 1998; Soderberg-Naucler et al., 2001; Goodrum et al., 2002; Reeves et al., 2005; Huang et al., 2012). During latency, HCMV remains present as an episome and produces a limited set of transcripts (Bolovan-Fritts et al., 1999; Goodrum et al., 2002; Bego et al., 2005; Cheung et al., 2006; Goodrum et al., 2007; Petrucelli et al., 2009; Avdic et al., 2011; Bego et al., 2011; Keyes et al., 2012; Poole et al., 2013; Rossetto et al., 2013).

After the identification of the first putative latency transcripts (Kondo and Mocarski, 1995; Kondo et al., 1996), several large scale studies have been set up to elucidate the latency-associated transcriptome. Upon infection of non-permissive cells, transcripts from 65 different loci have been observed which, over time, lead to robust expression of a discrete set of transcripts (Goodrum et al., 2002; Cheung et al., 2006; Rossetto et al., 2013). Noteworthy is that several of these identified transcripts, i.e., RL3, RL5, RL7, UL41, UL66, and UL131 were recently described not to code for proteins (Davison et al., 2013). Of the remaining transcripts, 30 were found in only one study by Goodrum et al. (2002), whilst UL28, UL37, UL50, UL52, UL95, UL114, UL123, UL126A, US27, RNA2.7, and RNA4.9 were found uniquely in another by Rossetto et al. (2013). Further studies also pinpointed UL82/pp71 and UL128 as possible latency-associated transcripts (LATs) (Cheung et al., 2006; Penkert and Kalejta, 2012).

A number of transcripts were found in more than one study, i.e., RL7, UL3, UL67, UL68, UL84, UL87, UL108, UL110, UL133, UL135, US28 (Beisser et al., 2002; Goodrum et al., 2002; Cheung et al., 2006; Keyes et al., 2012; Rossetto et al., 2013) but thus far only UL81ast/LUNA (Goodrum et al., 2002; Bego et al., 2005, 2011; Keyes et al., 2012; Rossetto et al., 2013), UL111A (Cheung et al., 2006; Avdic et al., 2011; Rossetto et al., 2013), UL138 (Goodrum et al., 2002, 2007; Petrucelli et al., 2009; Rossetto et al., 2013) and, depending on the virus used and the presence of GATA transcription binding sites, UL144 (Poole et al., 2013) were extensively characterized as LATs. Further research will show the validity of other potential LATs and dive deeper into the actual function of these transcripts and possibly their gene products during HCMV latency.

\section{NEW GENES INVOLVED IN IMMUNOMODULATION}

HCMV modulates both the host's innate and adaptive immunity though various pathways (Jackson et al., 2011; Noriega et al., 2012a). In fact, in our functional annotation, 14 HCMV gene products were attributed a new role, or a proposed role, in immunomodulation whilst the involvement of 19 genes in immunomodulation were further expanded or confirmed (Supplementary Table 1).

$\mathrm{HCMV}$ is well known to interfere with antigen presentation on MHC-I molecules thereby evading T-cell and NK-regulated immunity (Jackson et al., 2011; Noriega et al., 2012a). Since the last reviews (Dunn et al., 2003; Mocarski, 2007), the roles of HCMV products in modulation of MHC-I expression (US2,
US3, US10, US11, UL82/pp71), interference in antigen prestentation (US6) or their debilitating capacity on T-cell or NK cell recognition and function (UL16, UL18, UL141, UL142, US2) were further characterized (Wiertz et al., 1996; Cosman et al., 2001; Odeberg et al., 2003; Wills et al., 2005; Oresic et al., 2006; Dugan and Hewitt, 2008; Kim et al., 2008; Oresic and Tortorella, 2008; Ashiru et al., 2009; Muller et al., 2010; Park et al., 2010; Prod'homme et al., 2010; Noriega et al., 2012b; Penkert and Kalejta, 2012; Hesse et al., 2013; Smith et al., 2013). In addition, several gene products have a new role in immunomodulation. UL37.3 was found to be an MHC-I-like molecule encoded by the virus (Wyrwicz and Rychlewski, 2008; Revilleza et al., 2011). Alternatively, UL49.5 was found to influence MHC-I recognition by T-cells while UL11 caused functional paralysis of T-cells (Oosten et al., 2007; Gabaev et al., 2011).

HCMV also expresses an array of cytokine- and chemokinelike molecules (McSharry et al., 2012). The involvement of UL144, UL146, UL147, and US28 in cytokine- and chemokinemediated processes was already reported before; but several groups further delineated their function (Poole et al., 2008; Stropes et al., 2009; Luttichau, 2010). Also, it was shown that UL33 and UL78 form heteromers with CCR5 and CXCR4 chemokine receptors resulting in a predominantly negative effect on CCR5 and CXCR4 functions and expression; without altering the chemokine binding properties of both receptors (Tadagaki et al., 2012). Alternatively, UL7 was found to be involved in modulating cytokine expression in DCs and myleoid cell lines. Through a SLAM domain UL7 can also mediate cellular adhesion to monocyte-derived DCs (Engel et al., 2011). In addition, UL22A has been suggested to play a role in infected DCs (Raftery et al., 2009). Further, UL128 has been shown to modulate cytokine expression to induce PBMC proliferation (Zheng et al., 2012). Also US17 was recently implicated in modulation of host pathways by controlling the virion so that it elicits a balanced immune response (Gurczynski et al., 2014). For UL138 an apparently contradictory role has been described. UL138, a known LAT (Goodrum et al., 2007), upregulates TNFR surface expression and potentiates the action of TNF $\alpha$, two processes much associated with pro-inflammatory responses (Chu, 2013). However, $\mathrm{TNF} \alpha$ has been attributed reactivating properties and thus it is postulated that UL138 may sensitize latently infected cells to TNF $\alpha$-mediated reactivation of HCMV. Finally UL139 is proposed to have an immunomodulatory role due to its homology to CD24 whilst RL12 and RL13 are likely involved in limiting host antibodies through their IgG binding capacity (Qi et al., 2006; Cortese et al., 2012). Other genes such as US7, US9 and TRS have been predicted to be involved in immunomodulation (Apweiler et al., 2004).

\section{CONCLUSION}

The large genome of HCMV is expressed in a complex and tightly regulated temporal cascade. Numerous protein products of the virus are cis- and trans-acting factors which modulate viral and cellular gene expression thereby ensuring maximal efficiency of the viral replication whilst carefully minimalizing disruptive cellular processes such as apoptosis and immune defense. In this review, we focussed on updating the functional annotation of 
the complete HCMV genome. Functional annotations such as the one presented here, and previously published annotations (Dunn et al., 2003; Mocarski, 2007), can be an aid in transcriptome or proteomics studies. This functional annotation is useful to look at gene clusters with similar functions, to perform functional pathway analysis or may suggest future research goals to investigate if neighboring genes with an unknown function possibly fit the same annotation as the rest of the cluster. Continues efforts of various groups have provided a functional annotation of most of the HCMV gene products. However, the representation of several functional categories stand out. First of all, the large number of genes associated with latency is striking. While only four LATs have been extensively characterized, many more transcripts were found in high-throughput studies. The challenge lies in identifying protein products for these transcripts and to determine their true role during HCMV latency and reactivation. In addition, most of the recent findings reveal that many HCMV gene products are involved in immunomodulation. This is not unusual for a virus which persists for life but only now we are beginning to understand the true complexity of the various cellular pathways HCMV modulates. Further research is vital to compose the complete picture of all immunomodulatory pathways which HCMV uses to enable lytic and latent infection. It is interesting in this regard to investigate gene clusters, e.g., UL141-UL148 in which some genes products have been attributed a function in immunomodulation, e.g., UL141, UL142, UL144, UL146, UL147 whilst others (UL145, UL148, UL149, and UL150) have an unknown function. Future studies investigating these regions will provide information if currently unknown genes also play a role in immunomodulation.

The current table is based on the gene map of genomics and transcriptomics studies (Dunn et al., 2003; Gatherer et al., 2011). However, recently it was revealed that the coding capacity of HCMV is far greater than originally assumed. SternGinossar et al. (2012) reported no less than 751 translated ORFs and 53 novel proteins originating from ORFs not overlapping the known ORFs. As currently the function of these genes and proteins is unknown, further reductionist studies are required to determine their role in the viral life cycle.

\section{AUTHOR CONTRIBUTIONS}

Ellen Van Damme and Marnix Van Loock gathered and combined the information to functionally annotate the HCMV genome, and wrote the manuscript describing novel functions of HCMV genes during the viral life cycle.

\section{ACKNOWLEDGMENTS}

The authors would like to thank Professor Dr. John Sinclair for the fruitful discussions and Dr. Kenneth Simmen for reading the manuscript.

\section{SUPPLEMENTARY MATERIAL}

The Supplementary Material for this article can be found online at: http://www.frontiersin.org/journal/10.3389/fmicb.2014. 00218/abstract

\section{REFERENCES}

Adair, R., Douglas, E. R., Maclean, J. B., Graham, S. Y., Aitken, J. D., Jamieson, F. E., et al. (2002). The products of human cytomegalovirus genes UL23, UL24, UL43 and US22 are tegument components. J. Gen. Virol. 83, 1315-1324.

Adamo, J. E., Schroer, J., and Shenk, T. (2004). Human cytomegalovirus TRS1 protein is required for efficient assembly of DNA-containing capsids. J. Virol. 78, 10221-10229. doi: 10.1128/JVI.78.19.10221-10229.2004

Ahlqvist, J., and Mocarski, E. (2011). Cytomegalovirus UL103 controls virion and dense body egress. J. Virol. 85, 5125-5135. doi: 10.1128/JVI.01682-10

Akter, P., Cunningham, C., McSharry, B. P., Dolan, A., Addison, C., Dargan, D. J., et al. (2003). Two novel spliced genes in human cytomegalovirus. J. Gen. Virol. 84, 1117-1122. doi: 10.1099/vir.0.18952-0

Andre, E., Imbert-Marcille, B. M., Cantarovich, D., Besse, B., Ferre-Aubineau, V., and Billaudel, S. (1999). Use of reverse transcription polymerase chain reaction with colorimetric plate hybridization to detect a cytomegalovirus late spliced mRNA in polymorphonuclear leukocytes from renal transplant patients. Diagn. Microbiol. Infect. Dis. 34, 287-291. doi: 10.1016/S0732-8893(99)00043-7

Aoyagi, M., Gaspar, M., and Shenk, T. E. (2010). Human cytomegalovirus UL69 protein facilitates translation by associating with the mRNA cap-binding complex and excluding 4EBP1. Proc. Natl. Acad. Sci. U.S.A. 107, 2640-2645. doi: 10.1073/pnas.0914856107

Apweiler, R., Bairoch, A., Wu, C. H., Barker, W. C., Boeckmann, B., Ferro, S., et al. (2004). UniProt: the universal protein knowledgebase. Nucleic Acids Res. 32, D115-D119. doi: 10.1093/nar/gkh131

Arcangeletti, M. C., Rodighiero, I., Mirandola, P., De Conto, F., Covan, S., Germini, D., et al. (2011). Cell-cycle-dependent localization of human cytomegalovirus UL83 phosphoprotein in the nucleolus and modulation of viral gene expression in human embryo fibroblasts in vitro. J. Cell. Biochem. 112, 307-317. doi: $10.1002 / \mathrm{jcb} .22928$

Arnolds, K. L., Lares, A. P., and Spencer, J. V. (2013). The US27 gene product of human cytomegalovirus enhances signaling of host chemokine receptor CXCR4. Virology 439, 122-131. doi: 10.1016/j.virol.2013.02.006

Arrode, G., and Davrinche, C. (2003). Dendritic cells and HCMV crosspresentation. Curr. Top. Microbiol. Immunol. 276, 277-294. doi: 10.1007/9783-662-06508-2_13

Ashiru, O., Bennett, N. J., Boyle, L. H., Thomas, M., Trowsdale, J., and Wills, M. R. (2009). NKG2D ligand MICA is retained in the cis-Golgi apparatus by human cytomegalovirus protein UL142. J. Virol. 83, 12345-12354. doi: 10.1128/JVI.01175-09

Atalay, R., Zimmermann, A., Wagner, M., Borst, E., Benz, C., Messerle, M., et al. (2002). Identification and expression of human cytomegalovirus transcription units coding for two distinct fcgamma receptor homologs. J. Virol. 76, 8596-8608. doi: 10.1128/JVI.76.17.8596-8608.2002

Aucoin, D. P., Smith, G. B., Meiering, C. D., and Mocarski, E. S. (2006). Betaherpesvirus-conserved cytomegalovirus tegument protein ppUL32 (pp150) controls cytoplasmic events during virion maturation. J. Virol. 80, 8199-8210. doi: 10.1128/JVI.00457-06

Avdic, S., Cao, J. Z., Cheung, A. K., Abendroth, A., and Slobedman, B. (2011). Viral interleukin-10 expressed by human cytomegalovirus during the latent phase of infection modulates latently infected myeloid cell differentiation. J. Virol. 85, 7465-7471. doi: 10.1128/JVI.00088-11

Avdic, S., Cao, J. Z., McSharry, B. P., Clancy, L. E., Brown, R., Steain, M., et al. (2013). Human cytomegalovirus interleukin-10 polarizes monocytes toward a deactivated M2c phenotype to repress host immune responses. J. Virol. 87, 10273-10282. doi: 10.1128/JVI.00912-13

Baldick, C. J. Jr., and Shenk, T. (1996). Proteins associated with purified human cytomegalovirus particles. J. Virol. 70, 6097-6105.

Battista, M. C., Bergamini, G., Boccuni, M. C., Campanini, F., Ripalti, A., and Landini, M. P. (1999). Expression and characterization of a novel structural protein of human cytomegalovirus, pUL25. J. Virol. 73, 3800-3809.

Bayer, C., Varani, S., Wang, L., Walther, P., Zhou, S., Straschewski, S., et al. (2013). Human cytomegalovirus infection of M1 and M2 macrophages triggers inflammation and autologous T-cell proliferation. J. Virol. 87, 67-79. doi: 10.1128/JVI. 01585-12

Beck, S., and Barrell, B. (1991). An HCMV reading frame which has similarity with both the $\mathrm{V}$ and $\mathrm{C}$ regions of the TCR gamma chain. DNA Seq. 2, 33-38.

Bego, M. G., Keyes, L. R., Maciejewski, J., and St Jeor, S. C. (2011). Human cytomegalovirus latency-associated protein LUNA is expressed during HCMV infections in vivo. Arch. Virol. 156, 1847-1851. doi: 10.1007/s00705-011-1027-7 
Bego, M., Maciejewski, J., Khaiboullina, S., Pari, G., and St Jeor, S. (2005). Characterization of an antisense transcript spanning the UL8182 locus of human cytomegalovirus. J. Virol. 79, 11022-11034. doi: 10.1128/JVI.79.17.11022-11034.2005

Beisser, P. S., Goh, C. S., Cohen, F. E., and Michelson, S. (2002). Viral chemokine receptors and chemokines in human cytomegalovirus trafficking and interaction with the immune system. CMV chemokine receptors. Curr. Top. Microbiol. Immunol. 269, 203-234. doi: 10.1007/978-3-642-59421-2_13

Beisser, P. S., Laurent, L., Virelizier, J. L., and Michelson, S. (2001). Human cytomegalovirus chemokine receptor gene US28 is transcribed in latently infected THP-1 monocytes. J. Virol. 75, 5949-5957. doi: 10.1128/JVI.75.13.5949-5957.2001

Bergallo, M., Costa, C., Terlizzi, M. E., Margio, S., Sidoti, F., Astegiano, S., et al. (2008). Reverse transcriptase-polymerase chain reaction to evaluate human cytomegalovirus lytic gene expression. Mol. Biotechnol. 40, 144-150. doi: 10.1007/s12033-008-9070-7

Bevan, I. S., Daw, R. A., Day, P. J., Ala, F. A., and Walker, M. R. (1991). Polymerase chain reaction for detection of human cytomegalovirus infection in a blood donor population. Br. J. Haematol. 78, 94-99. doi: 10.1111/j.13652141.1991.tb04388.x

Biegalke, B. J. (1999). Human cytomegalovirus US3 gene expression is regulated by a complex network of positive and negative regulators. Virology 261, 155-164. doi: 10.1006/viro.1999.9881

Biegalke, B. J., Lester, E., Branda, A., and Rana, R. (2004). Characterization of the human cytomegalovirus UL34 gene. J. Virol. 78, 9579-9583. doi: 10.1128/JVI.78.17.9579-9583.2004

Bierle, C. J., Semmens, K. M., and Geballe, A. P. (2013). Double-stranded RNA binding by the human cytomegalovirus PKR antagonist TRS1. Virology 442, 28-37. doi: 10.1016/j.virol.2013.03.024

Bigley, T. M., Reitsma, J. M., Mirza, S. P., and Terhune, S. S. (2013). Human cytomegalovirus pUL97 regulates the viral major immediate early promoter by phosphorylation-mediated disruption of histone deacetylase 1 binding. J. Virol. 87, 7393-7408. doi: 10.1128/JVI.02825-12

Blankenship, C. A., and Shenk, T. (2002). Mutant human cytomegalovirus lacking the immediate-early TRS1 coding region exhibits a late defect. J. Virol. 76, 12290-12299. doi: 10.1128/JVI.76.23.12290-12299.2002

Boeckh, M., and Geballe, A. P. (2011). Cytomegalovirus: pathogen, paradigm, and puzzle. J. Clin. Invest. 121, 1673-1680. doi: 10.1172/JCI45449

Bogdanow, B., Weisbach, H., Von Einem, J., Straschewski, S., Voigt, S., Winkler, M., et al. (2013). Human cytomegalovirus tegument protein pp150 acts as a cyclin A2-CDK-dependent sensor of the host cell cycle and differentiation state. Proc. Natl. Acad. Sci. U.S.A. 110, 17510-17515. doi: 10.1073/pnas. 1312235110

Bolovan-Fritts, C. A., Mocarski, E. S., and Wiedeman, J. A. (1999). Peripheral blood $\mathrm{CD} 14(+)$ cells from healthy subjects carry a circular conformation of latent cytomegalovirus genome. Blood 93, 394-398.

Boriskin, Y. S., and Butcher, P. D. (2001). Human cytomegalovirus UL21.5 gene is expressed as an "early-late" gene in cultured human fibroblasts. Acta Virol. 45, 185-189.

Borst, E. M., Kleine-Albers, J., Gabaev, I., Babic, M., Wagner, K., Binz, A., et al. (2013). The human cytomegalovirus UL51 protein is essential for viral genome cleavage-packaging and interacts with the terminase subunits pUL56 and pUL89. J. Virol. 87, 1720-1732. doi: 10.1128/JVI.01955-12

Borst, E. M., Wagner, K., Binz, A., Sodeik, B., and Messerle, M. (2008). The essential human cytomegalovirus gene UL52 is required for cleavage-packaging of the viral genome. J. Virol. 82, 2065-2078. doi: 10.1128/JVI.01967-07

Boutet, E., Lieberherr, D., Tognolli, M., Schneider, M., and Bairoch, A. (2007). UniProtKB/Swiss-Prot. Methods Mol. Biol. 406, 89-112. doi: 10.1007/978-159745-535-0 4

Bradley, A. J., Kovacs, I. J., Gatherer, D., Dargan, D. J., Alkharsah, K. R., Chan, P. K., et al. (2008). Genotypic analysis of two hypervariable human cytomegalovirus genes. J. Med. Virol. 80, 1615-1623. doi: 10.1002/jmv.21241

Bronzini, M., Luganini, A., Dell'oste, V., De Andrea, M., Landolfo, S., and Gribaudo, G. (2012). The US16 gene of human cytomegalovirus is required for efficient viral infection of endothelial and epithelial cells. J. Virol. 86, 6875-6888. doi: 10.1128/JVI.06310-11

Buchkovich, N. J., Maguire, T. G., and Alwine, J. C. (2010). Role of the endoplasmic reticulum chaperone BiP, SUN domain proteins, and dynein in altering nuclear morphology during human cytomegalovirus infection. J. Virol. 84, 7005-7017. doi: 10.1128/JVI.00719-10
Buchkovich, N. J., Maguire, T. G., Paton, A. W., Paton, J. C., and Alwine, J. C. (2009). The endoplasmic reticulum chaperone BiP/GRP78 is important in the structure and function of the human cytomegalovirus assembly compartment. J. Virol. 83, 11421-11428. doi: 10.1128/JVI.00762-09

Bughio, F., Elliott, D. A., and Goodrum, F. (2013). An endothelial cell-specific requirement for the UL133-UL138 locus of human cytomegalovirus for efficient virus maturation. J. Virol. 87, 3062-3075. doi: 10.1128/JVI.02510-12

Caffarelli, N., Fehr, A. R., and Yu, D. (2013). Cyclin A degradation by primate cytomegalovirus protein pUL21a counters its innate restriction of virus replication. PLoS Pathog. 9:e1003825. doi: 10.1371/journal.ppat.10 03825

Cannon, M. J., Schmid, D. S., and Hyde, T. B. (2010). Review of cytomegalovirus seroprevalence and demographic characteristics associated with infection. Rev. Med. Virol. 20, 202-213. doi: 10.1002/rmv.655

Cassady, K. A. (2005). Human cytomegalovirus TRS1 and IRS1 gene products block the double-stranded-RNA-activated host protein shutoff response induced by herpes simplex virus type 1 infection. J. Virol. 79, 8707-8715. doi: 10.1128/JVI.79.14.8707-8715.2005

Chambers, J., Angulo, A., Amaratunga, D., Guo, H., Jiang, Y., Wan, J. S., et al. (1999). DNA microarrays of the complex human cytomegalovirus genome: profiling kinetic class with drug sensitivity of viral gene expression. J. Virol. 73, 5757-5766.

Champier, G., Couvreux, A., Hantz, S., Rametti, A., Mazeron, M. C., Bouaziz, S., et al. (2008). Putative functional domains of human cytomegalovirus pUL56 involved in dimerization and benzimidazole D-ribonucleoside activity. Antivir. Ther. 13, 643-654.

Chang, C. P., Vesole, D. H., Nelson, J., Oldstone, M. B., and Stinski, M. F. (1989). Identification and expression of a human cytomegalovirus early glycoprotein. J. Virol. 63, 3330-3337.

Chang, W. L., Baumgarth, N., Yu, D., and Barry, P. A. (2004). Human cytomegalovirus-encoded interleukin-10 homolog inhibits maturation of dendritic cells and alters their functionality. J. Virol. 78, 8720-8731. doi: 10.1128/JVI.78.16.8720-8731.2004

Chang, Y. E., and Roizman, B. (1993). The product of the UL31 gene of herpes simplex virus 1 is a nuclear phosphoprotein which partitions with the nuclear matrix. J. Virol. 67, 6348-6356.

Chapman, T. L., Heikeman, A. P., and Bjorkman, P. J. (1999). The inhibitory receptor LIR-1 uses a common binding interaction to recognize class I MHC molecules and the viral homolog UL18. Immunity 11, 603-613. doi: 10.1016/S1074-7613(00)80135-1

Chaumorcel, M., Lussignol, M., Mouna, L., Cavignac, Y., Fahie, K., Cotte-Laffitte, J., et al. (2012). The human cytomegalovirus protein TRS1 inhibits autophagy via its interaction with Beclin 1. J. Virol. 86, 2571-2584. doi: 10.1128/JVI. 05746-11

Cheung, A. K., Abendroth, A., Cunningham, A. L., and Slobedman, B. (2006). Viral gene expression during the establishment of human cytomegalovirus latent infection in myeloid progenitor cells. Blood 108, 3691-3699. doi: 10.1182/blood-2005-12-026682

Cheung, A. K., Gottlieb, D. J., Plachter, B., Pepperl-Klindworth, S., Avdic, S., Cunningham, A. L., et al. (2009). The role of the human cytomegalovirus UL111A gene in down-regulating CD4+ T-cell recognition of latently infected cells: implications for virus elimination during latency. Blood 114, 4128-4137. doi: 10.1182/blood-2008-12-197111

Child, S. J., Brennan, G., Braggin, J. E., and Geballe, A. P. (2012). Species specificity of protein kinase $\mathrm{r}$ antagonism by cytomegalovirus TRS1 genes. J. Virol. 86, 3880-3889. doi: 10.1128/JVI.06158-11

Child, S. J., Hakki, M., De Niro, K. L., and Geballe, A. P. (2004). Evasion of cellular antiviral responses by human cytomegalovirus TRS1 and IRS1. J. Virol. 78, 197-205. doi: 10.1128/JVI.78.1.197-205.2004

Chu, W. M. (2013). Tumor necrosis factor. Cancer Lett. 328, 222-225. doi: 10.1016/j.canlet.2012.10.014

Colberg-Poley, A. M. (1996). Functional roles of immediate early proteins encoded by the human cytomegalovirus UL36-38, UL115-119, TRS1/IRS1 and US3 loci. Intervirology 39, 350-360.

Colberg-Poley, A. M., Santomenna, L. D., Harlow, P. P., Benfield, P. A., and Tenney, D. J. (1992). Human cytomegalovirus US3 and UL36-38 immediate-early proteins regulate gene expression. J. Virol. 66, 95-105.

Colletti, K. S., Smallenburg, K. E., Xu, Y., and Pari, G. S. (2007). Human cytomegalovirus UL84 interacts with an RNA stem-loop sequence found 
within the RNA/DNA hybrid region of oriLyt. J. Virol. 81, 7077-7085. doi: 10.1128/JVI.00058-07

Cortese, M., Calo, S., D'aurizio, R., Lilja, A., Pacchiani, N., and Merola, M. (2012). Recombinant human cytomegalovirus (HCMV) RL13 binds human immunoglobulin G Fc. PLoS ONE 7:e50166. doi: 10.1371/journal.pone.0050166

Cosman, D., Mullberg, J., Sutherland, C. L., Chin, W., Armitage, R., Fanslow, W., et al. (2001). ULBPs, novel MHC class I-related molecules, bind to CMV glycoprotein UL16 and stimulate NK cytotoxicity through the NKG2D receptor. Immunity 14, 123-133. doi: 10.1016/S1074-7613(01)00095-4

Costa, H., Nascimento, R., Sinclair, J., and Parkhouse, R. M. (2013). Human cytomegalovirus gene UL76 induces IL-8 expression through activation of the DNA damage response. PLoS Pathog. 9:e1003609. doi: 10.1371/journal.ppat.1003609

Cristea, I. M., Moorman, N. J., Terhune, S. S., Cuevas, C. D., O'keefe, E. S., Rout, M. P., et al. (2010). Human cytomegalovirus pUL83 stimulates activity of the viral immediate-early promoter through its interaction with the cellular IFI16 protein. J. Virol. 84, 7803-7814. doi: 10.1128/JVI.00139-10

Crough, T., and Khanna, R. (2009). Immunobiology of human cytomegalovirus: from bench to bedside. Clin. Microbiol. Rev. 22, 76-98 doi: 10.1128/CMR.00 034-08

Dal Monte, P., Pignatelli, S., Zini, N., Maraldi, N. M., Perret, E., Prevost, M. C., et al. (2002). Analysis of intracellular and intraviral localization of the human cytomegalovirus UL53 protein. J. Gen. Virol. 83, 1005-1012.

Davison, A. J., Holton, M., Dolan, A., Dargan, D. J., Gatherer, D., and Hayward, G. S. (2013). "E-Chapter 1, Volume 1: comparative genomics of primate cytomegaloviruses," in Cytomegaloviruses: From Molecular Pathogenesis to Intervention, ed M. J. Reddehase (Mainz: Caister Academic Press), 1-22.

Dhuruvasan, K., Sivasubramanian, G., and Pellett, P. E. (2011). Roles of host and viral microRNAs in human cytomegalovirus biology. Virus Res. 157, 180-192. doi: $10.1016 /$ j.virusres.2010.10.011

Dolan, A., Cunningham, C., Hector, R. D., Hassan-Walker, A. F., Lee, L., Addison, C., et al. (2004). Genetic content of wild-type human cytomegalovirus. J. Gen. Virol. 85, 1301-1312. doi: 10.1099/vir.0.79888-0

Dugan, G. E., and Hewitt, E. W. (2008). Structural and functional dissection of the human cytomegalovirus immune evasion protein US6. J. Virol. 82, 3271-3282. doi: 10.1128/JVI.01705-07

Dunn, W., Chou, C., Li, H., Hai, R., Patterson, D., Stolc, V., et al. (2003). Functional profiling of a human cytomegalovirus genome. Proc. Natl. Acad. Sci. U.S.A. 100, 14223-14228. doi: 10.1073/pnas.2334032100

Durose, J. B., Li, J., Chien, S., and Spector, D. H. (2012). Infection of vascular endothelial cells with human cytomegalovirus under fluid shear stress reveals preferential entry and spread of virus in flow conditions simulating atheroprone regions of the artery. J. Virol. 86, 13745-13755. doi: 10.1128/JVI. 02244-12

Engel, P., Perez-Carmona, N., Alba, M. M., Robertson, K., Ghazal, P., and Angulo, A. (2011). Human cytomegalovirus UL7, a homologue of the SLAM-family receptor CD229, impairs cytokine production. Immunol. Cell Biol. 89, 753-766. doi: $10.1038 /$ icb. 2011.55

Fehr, A. R., and Yu, D. (2010). Human cytomegalovirus gene UL21a encodes a short-lived cytoplasmic protein and facilitates virus replication in fibroblasts. J. Virol. 84, 291-302. doi: 10.1128/JVI.01116-09

Fehr, A. R., and Yu, D. (2011). Human cytomegalovirus early protein pUL21a promotes efficient viral DNA synthesis and the late accumulation of immediateearly transcripts. J. Virol. 85, 663-674. doi: 10.1128/JVI.01599-10

Feng, X., Schroer, J., Yu, D., and Shenk, T. (2006). Human cytomegalovirus pUS24 is a virion protein that functions very early in the replication cycle. J. Virol. 80, 8371-8378. doi: 10.1128/JVI.00399-06

Fliss, P. M., and Brune, W. (2012). Prevention of cellular suicide by cytomegaloviruses. Viruses 4, 1928-1949. doi: 10.3390/v4101928

Fulcher, A. J., and Jans, D. A. (2011). Regulation of nucleocytoplasmic trafficking of viral proteins: an integral role in pathogenesis? Biochim. Biophys. Acta 1813, 2176-2190. doi: 10.1016/j.bbamcr.2011.03.019

Gabaev, I., Steinbruck, L., Pokoyski, C., Pich, A., Stanton, R. J., Schwinzer, R., et al. (2011). The human cytomegalovirus UL11 protein interacts with the receptor tyrosine phosphatase CD45, resulting in functional paralysis of T cells. PLoS Pathog. 7:e1002432. doi: 10.1371/journal.ppat.1002432

Gao, Y., Kagele, D., Smallenberg, K., and Pari, G. S. (2010). Nucleocytoplasmic shuttling of human cytomegalovirus UL84 is essential for virus growth. J. Virol. 84, 8484-8494. doi: 10.1128/JVI.00738-10
Gao, Y., and Pari, G. S. (2009). Interaction of human cytomegalovirus pUL84 with casein kinase 2 is required for oriLyt-dependent DNA replication. J. Virol. 83, 2393-2396. doi: 10.1128/JVI.02339-08

Gatherer, D., Seirafian, S., Cunningham, C., Holton, M., Dargan, D. J., Baluchova, K., et al. (2011). High-resolution human cytomegalovirus transcriptome. Proc. Natl. Acad. Sci. U.S.A. 108, 19755-19760. doi: 10.1073/pnas.1115861108

Gibson, W. (2008a). Structure and formation of the cytomegalovirus virion. Curr. Top. Microbiol. Immunol. 325, 187-204. doi: 10.1007/978-3-540-77349-8_11

Gibson, W. (2008b). "Structure and fortmation of the cytomegalovirus virion," in Human Cytomegalovirus, eds T. Shenk and M. F. Stinski (Berlin; Heidelberg: Springer-Verlag), 187-204.

Goodrum, F. D., Jordan, C. T., High, K., and Shenk, T. (2002). Human cytomegalovirus gene expression during infection of primary hematopoietic progenitor cells: a model for latency. Proc. Natl. Acad. Sci. U.S.A. 99, 16255-16260. doi: 10.1073/pnas.252630899

Goodrum, F., Reeves, M., Sinclair, J., High, K., and Shenk, T. (2007). Human cytomegalovirus sequences expressed in latently infected individuals promote a latent infection in vitro. Blood 110, 937-945. doi: 10.1182/blood-2007-01070078

Griffiths, P. D. (2006). CMV as a cofactor enhancing progression of AIDS. J. Clin. Virol. 35, 489-492. doi: 10.1016/j.jcv.2005.10.016

Guo, Y. W., and Huang, E. S. (1993). Characterization of a structurally tricistronic gene of human cytomegalovirus composed of $\mathrm{U}(\mathrm{s}) 18, \mathrm{U}(\mathrm{s}) 19$, and $\mathrm{U}(\mathrm{s}) 20$. J. Virol. 67, 2043-2054.

Gurczynski, S. J., Das, S., and Pellett, P. E. (2014). Deletion of the human cytomegalovirus US17 gene increases the ratio of genomes per infectious unit and alters regulation of immune and endoplasmic reticulum stress response genes at early and late times after infection. J. Virol. 88, 2168-2182. doi: 10.1128/JVI.02704-13

Hahn, G., Jores, R., and Mocarski, E. S. (1998). Cytomegalovirus remains latent in a common precursor of dendritic and myeloid cells. Proc. Natl. Acad. Sci. U.S.A. 95, 3937-3942. doi: 10.1073/pnas.95.7.3937

Hakki, M., Marshall, E. E., De Niro, K. L., and Geballe, A. P. (2006). Binding and nuclear relocalization of protein kinase R by human cytomegalovirus TRS1. J. Virol. 80, 11817-11826. doi: 10.1128/JVI.00957-06

Hassan-Walker, A. F., Cope, A. V., Griffiths, P. D., and Emery, V. C. (1998). Transcription of the human cytomegalovirus natural killer decoy gene, UL18, in vitro and in vivo. J. Gen. Virol. 79(Pt 9), 2113-2116.

Hayajneh, W. A., Contopoulos-Ioannidis, D. G., Lesperance, M. M., Venegas, A. M., and Colberg-Poley, A. M. (2001). The carboxyl terminus of the human cytomegalovirus UL37 immediate-early glycoprotein is conserved in primary strains and is important for transactivation. J. Gen. Virol. 82, 1569-1579.

Henaff, D., Radtke, K., and Lippe, R. (2012). Herpesviruses exploit several host compartments for envelopment. Traffic 13, 1443-1449. doi: 10.1111/j.16000854.2012.01399.x

Heo, J., Petheram, S., Demmler, G., Murph, J. R., Adler, S. P., Bale, J., et al. (2008). Polymorphisms within human cytomegalovirus chemokine (UL146/UL147) and cytokine receptor genes (UL144) are not predictive of sequelae in congenitally infected children. Virology 378, 86-96. doi: 10.1016/j.virol.2008.05.002

Hesse, J., Ameres, S., Besold, K., Krauter, S., Moosmann, A., and Plachter, B. (2013). Suppression of CD8+ T-cell recognition in the immediate-early phase of human cytomegalovirus infection. J. Gen. Virol. 94, 376-386. doi: 10.1099/vir.0.04 5682-0

Hitomi, S., Kozuka-Hata, H., Chen, Z., Sugano, S., Yamaguchi, N., and Watanabe, S. (1997). Human cytomegalovirus open reading frame UL11 encodes a highly polymorphic protein expressed on the infected cell surface. Arch. Virol. 142, 1407-1427. doi: 10.1007/s007050050169

Hofmann, H., Sindre, H., and Stamminger, T. (2002). Functional interaction between the pp71 protein of human cytomegalovirus and the PML-interacting protein human Daxx. J. Virol. 76, 5769-5783. doi: 10.1128/JVI.76.11.57695783.2002

Homer, E. G., Rinaldi, A., Nicholl, M. J., and Preston, C. M. (1999). Activation of herpesvirus gene expression by the human cytomegalovirus protein pp71. J. Virol. 73, 8512-8518.

Huang, M. M., Kew, V. G., Jestice, K., Wills, M. R., and Reeves, M. B. (2012). Efficient human cytomegalovirus reactivation is maturation dependent in the Langerhans dendritic cell lineage and can be studied using a CD14+ experimental latency model. J. Virol. 86, 8507-8515. doi: 10.1128/JVI. 00598-12 
Huber, M. T., and Compton, T. (1998). The human cytomegalovirus UL74 gene encodes the third component of the glycoprotein H-glycoprotein L-containing envelope complex. J. Virol. 72, 8191-8197.

Hutchinson, N. I., Sondermeyer, R. T., and Tocci, M. J. (1986). Organization and expression of the major genes from the long inverted repeat of the human cytomegalovirus genome. Virology 155, 160-171. doi: 10.1016/00426822(86)90176-5

Hyun, J. J., Park, H. S., Kim, K. H., and Kim, H. J. (1999). Analysis of transcripts expressed from the UL47 gene of human cytomegalovirus. Arch. Pharm. Res. 22, 542-548. doi: 10.1007/BF02975323

Isaacson, M. K., and Compton, T. (2009). Human cytomegalovirus glycoprotein B is required for virus entry and cell-to-cell spread but not for virion attachment, assembly, or egress. J. Virol. 83, 3891-3903. doi: 10.1128/JVI.01251-08

Isomura, H., Stinski, M. F., Murata, T., Nakayama, S., Chiba, S., Akatsuka, Y., et al. (2010). The human cytomegalovirus UL76 gene regulates the level of expression of the UL77 gene. PLOS ONE 5:e11901. doi: 10.1371/journal.pone. 0011901

Isomura, H., Stinski, M. F., Murata, T., Yamashita, Y., Kanda, T., Toyokuni, S., et al. (2011). The human cytomegalovirus gene products essential for late viral gene expression assemble into prereplication complexes before viral DNA replication. J. Virol. 85, 6629-6644. doi: 10.1128/JVI.00384-11

Iwayama, S., Yamamoto, T., Furuya, T., Kobayashi, R., Ikuta, K., and Hirai, K. (1994). Intracellular localization and DNA-binding activity of a class of viral early phosphoproteins in human fibroblasts infected with human cytomegalovirus (Towne strain). J. Gen. Virol. 75(Pt 12), 3309-3318. doi: 10.1099/0022-1317-75-12-3309

Jackson, S. E., Mason, G. M., and Wills, M. R. (2011). Human cytomegalovirus immunity and immune evasion. Virus Res. 157, 151-160. doi: 10.1016/j. virusres.2010.10.031

Jelcic, I., Reichel, J., Schlude, C., Treutler, E., Sinzger, C., and Steinle, A. (2011). The polymorphic HCMV glycoprotein UL20 is targeted for lysosomal degradation by multiple cytoplasmic dileucine motifs. Traffic 12, 1444-1456. doi: 10.1111/j. 1600-0854.2011.01236.x

Jenkins, C., Abendroth, A., and Slobedman, B. (2004). A novel viral transcript with homology to human interleukin-10 is expressed during latent human cytomegalovirus infection. J. Virol. 78, 1440-1447. doi: 10.1128/JVI.78.3.14401447.2004

Jenkins, C., Garcia, W., Abendroth, A., and Slobedman, B. (2008). Expression of a human cytomegalovirus latency-associated homolog of interleukin10 during the productive phase of infection. Virology 370, 285-294. doi: 10.1016/j.virol.2007.09.002

Jiang, X. J., Adler, B., Sampaio, K. L., Digel, M., Jahn, G., Ettischer, N., et al. (2008). UL74 of human cytomegalovirus contributes to virus release by promoting secondary envelopment of virions. J. Virol. 82, 2802-2812. doi: 10.1128/JVI.01550-07

Jiang, X. J., Sampaio, K. L., Ettischer, N., Stierhof, Y. D., Jahn, G., Kropff, B., et al. (2011). UL74 of human cytomegalovirus reduces the inhibitory effect of gH-specific and gB-specific antibodies. Arch. Virol. 156, 2145-2155. doi: 10.1007/s00705-011-1105-x

Jones, T. R., Muzithras, V. P., and Gluzman, Y. (1991). Replacement mutagenesis of the human cytomegalovirus genome: US10 and US11 gene products are nonessential. J. Virol. 65, 5860-5872.

Kagele, D., Gao, Y., Smallenburg, K., and Pari, G. S. (2009). Interaction of HCMV UL84 with C/EBPalpha transcription factor binding sites within oriLyt is essential for lytic DNA replication. Virology 392, 16-23. doi: 10.1016/j.virol.2009.06.035

Kalejta, R. F. (2008). Tegument proteins of human cytomegalovirus. Microbiol. Mol. Biol. Rev. 72, 249-265. doi: 10.1128/MMBR.00040-07

Kapasi, A. J., and Spector, D. H. (2008). Inhibition of the cyclin-dependent kinases at the beginning of human cytomegalovirus infection specifically alters the levels and localization of the RNA polymerase II carboxyl-terminal domain kinases cdk9 and cdk7 at the viral transcriptosome. J. Virol. 82, 394-407. doi: 10.1128/JVI.01681-07

Kaye, J., Browne, H., Stoffel, M., and Minson, T. (1992). The UL16 gene of human cytomegalovirus encodes a glycoprotein that is dispensable for growth in vitro. J. Virol. 66, 6609-6615.

Kenneson, A., and Cannon, M. J. (2007). Review and meta-analysis of the epidemiology of congenital cytomegalovirus (CMV) infection. Rev. Med. Virol. 17, 253-276. doi: 10.1002/rmv.535
Keyes, L. R., Hargett, D., Soland, M., Bego, M. G., Rossetto, C. C., Almeida-Porada, G., et al. (2012). HCMV protein LUNA is required for viral reactivation from latently infected primary CD14(+) cells. PLoS ONE 7:e52827. doi: 10.1371/journal.pone.0052827

Kim, E. T., Oh, S. E., Lee, Y. O., Gibson, W., and Ahn, J. H. (2009). Cleavage specificity of the UL48 deubiquitinating protease activity of human cytomegalovirus and the growth of an active-site mutant virus in cultured cells. J. Virol. 83, 12046-12056. doi: 10.1128/JVI.00411-09

Kim, Y. E., and Ahn, J. H. (2010). Role of the specific interaction of UL112-113 p84 with UL44 DNA polymerase processivity factor in promoting DNA replication of human cytomegalovirus. J. Virol. 84, 8409-8421. doi: 10.1128/JVI.00189-10

Kim, Y., Park, B., Cho, S., Shin, J., Cho, K., Jun, Y., et al. (2008). Human cytomegalovirus UL18 utilizes US6 for evading the NK and T-cell responses. PLoS Pathog. 4:e1000123. doi: 10.1371/journal.ppat.1000123

Kinzler, E. R., and Compton, T. (2005). Characterization of human cytomegalovirus glycoprotein-induced cell-cell fusion. J. Virol. 79, 7827-7837. doi: 10.1128/JVI.79.12.7827-7837.2005

Knoblach, T., Grandel, B., Seiler, J., Nevels, M., and Paulus, C. (2011). Human cytomegalovirus IE1 protein elicits a type II interferon-like host cell response that depends on activated STAT1 but not interferon-gamma. PLoS Pathog. 7:e1002016. doi: 10.1371/journal.ppat.1002016

Kondo, K., and Mocarski, E. S. (1995). Cytomegalovirus latency and latencyspecific transcription in hematopoietic progenitors. Scand. J. Infect. Dis. Suppl. 99, 63-67.

Kondo, K., Xu, J., and Mocarski, E. S. (1996). Human cytomegalovirus latent gene expression in granulocyte-macrophage progenitors in culture and in seropositive individuals. Proc. Natl. Acad. Sci. U.S.A. 93, 11137-11142. doi: 10.1073/pnas.93.20.11137

Krzyzaniak, M., Mach, M., and Britt, W. J. (2007). The cytoplasmic tail of glycoprotein M (gpUL100) expresses trafficking signals required for human cytomegalovirus assembly and replication. J. Virol. 81, 10316-10328. doi: 10.1128/JVI.00375-07

Kwon, Y., Kim, M. N., Young Choi, E., Heon Kim, J., Hwang, E. S., and Cha, C. Y. (2012). Inhibition of p53 transcriptional activity by human cytomegalovirus UL44. Microbiol. Immunol. 56, 324-331. doi: 10.1111/j.1348-0421.2012.00446.x

Lares, A. P., Tu, C. C., and Spencer, J. V. (2013). The human cytomegalovirus US27 gene product enhances cell proliferation and alters cellular gene expression. Virus Res. 176, 312-320. doi: 10.1016/j.virusres.2013.07.002

Lashmit, P. E., Lundquist, C. A., Meier, J. L., and Stinski, M. F. (2004). Cellular repressor inhibits human cytomegalovirus transcription from the UL127 promoter. J. Virol. 78, 5113-5123. doi: 10.1128/JVI.78.10.5113-5123.2004

Le, V. T., Trilling, M., and Hengel, H. (2011). The cytomegaloviral protein pUL138 acts as potentiator of tumor necrosis factor (TNF) receptor 1 surface density to enhance ULb'-encoded modulation of TNF-alpha signaling. J. Virol. 85, 13260-13270. doi: 10.1128/JVI.06005-11

Liu, Y., and Biegalke, B. J. (2002). The human cytomegalovirus UL35 gene encodes two proteins with different functions. J. Virol. 76, 2460-2468. doi: 10.1128/jvi.76.5.2460-2468.2002

Loveland, A. N., Nguyen, N. L., Brignole, E. J., and Gibson, W. (2007). The aminoconserved domain of human cytomegalovirus UL80a proteins is required for key interactions during early stages of capsid formation and virus production. J. Virol. 81, 620-628. doi: 10.1128/JVI.01903-06

Lurain, N. S., Fox, A. M., Lichy, H. M., Bhorade, S. M., Ware, C. F., Huang, D. D., et al. (2006). Analysis of the human cytomegalovirus genomic region from UL146 through UL147A reveals sequence hypervariability, genotypic stability, and overlapping transcripts. Virol. J. 3, 4. doi: 10.1186/1743-422X-3-4

Luttichau, H. R. (2010). The cytomegalovirus UL146 gene product vCXCL1 targets both CXCR1 and CXCR2 as an agonist. J. Biol. Chem. 285, 9137-9146. doi: 10.1074/jbc.M109.002774

Ma, Y., Gao, S., Wang, L., Wang, N., Li, M., Zheng, B., et al. (2014). Analysis and mapping of a 3' coterminal transcription unit derived from human cytomegalovirus open reading frames UL30-UL32. Virol. J. 10, 65. doi: 10.1186/1743-422X-10-65

Ma, Y., Li, M., Zheng, B., Wang, N., Gao, S., Wang, L., et al. (2013). Overlapping transcription structure of human cytomegalovirus UL140 and UL141 genes. J. Biosci. 38, 35-44. doi: 10.1007/s12038-012-9293-4

Marshall, E. E., Bierle, C. J., Brune, W., and Geballe, A. P. (2009). Essential role for either TRS1 or IRS1 in human cytomegalovirus replication. J. Virol. 83, 4112-4120. doi: 10.1128/JVI.02489-08 
Martinez, F. P., Cruz, R., Lu, F., Plasschaert, R., Deng, Z., Rivera-Molina, Y. A., et al. (2014). CTCF binding to the first intron of the major immediate-early (MIE) gene of human cytomegalovirus (HCMV) negatively regulates MIE gene expression and HCMV replication. J. Virol. doi: 10.1128/JVI.00845-14. [Epub ahead of print].

Maussang, D., Langemeijer, E., Fitzsimons, C. P., Stigter-Van Walsum, M., Dijkman, R., Borg, M. K., et al. (2009). The human cytomegalovirus-encoded chemokine receptor US28 promotes angiogenesis and tumor formation via cyclooxygenase2. Cancer Res. 69, 2861-2869. doi: 10.1158/0008-5472.CAN-08-2487

Maussang, D., Verzijl, D., Van Walsum, M., Leurs, R., Holl, J., Pleskoff, O., et al. (2006). Human cytomegalovirus-encoded chemokine receptor US28 promotes tumorigenesis. Proc. Natl. Acad. Sci. U.S.A. 103, 13068-13073. doi: 10.1073/pnas.0604433103

McCormick, A. L., Roback, L., Livingston-Rosanoff, D., and St Clair, C. (2010). The human cytomegalovirus UL36 gene controls caspase-dependent and independent cell death programs activated by infection of monocytes differentiating to macrophages. J. Virol. 84, 5108-5123. doi: 10.1128/JVI.01345-09

McSharry, B. P., Avdic, S., and Slobedman, B. (2012). Human cytomegalovirus encoded homologs of cytokines, chemokines and their receptors: roles in immunomodulation. Viruses 4, 2448-2470. doi: 10.3390/v4112448

Meier, J. L., and Stinski, M. F. (1996). Regulation of human cytomegalovirus immediate-early gene expression. Intervirology 39, 331-342.

Meissner, C. S., Koppen-Rung, P., Dittmer, A., Lapp, S., and Bogner, E. (2011). A "coiled-coil" motif is important for oligomerization and DNA binding properties of human cytomegalovirus protein UL77. PLOS ONE 6:e25115. doi: 10.1371/journal.pone.0025115

Meissner, C. S., Suffner, S., Schauflinger, M., Von Einem, J., and Bogner, E. (2012). A leucine zipper motif of a tegument protein triggers final envelopment of human cytomegalovirus. J. Virol. 86, 3370-3382. doi: 10.1128/JVI.06556-11

Mendelson, M., Monard, S., Sissons, P., and Sinclair, J. (1996). Detection of endogenous human cytomegalovirus in CD34+ bone marrow progenitors. J. Gen. Virol. 77(Pt 12), 3099-3102. doi: 10.1099/0022-1317-77-12-3099

Mitchell, D. P., Savaryn, J. P., Moorman, N. J., Shenk, T., and Terhune, S. S. (2009). Human cytomegalovirus UL28 and UL29 open reading frames encode a spliced mRNA and stimulate accumulation of immediate-early RNAs. J. Virol. 83, 10187-10197. doi: 10.1128/JVI.00396-09

Mocarski, E. Jr. (1996). “Cytomegalovirus and their replication," in Virology, eds B. N. Fields, K. M. Knipe, and P. M. Howley (Philadelphia, PA: Lippincott-Raven Publishers), 2447.

Mocarski, E. Jr. (2007). "Betaherpes viral genes and their functions," in Human Herpesviruses: Biology, Therapy, and Immunoprophylaxis, Chapter 15, eds A. Arvin, G. Campadelli-Fiume, E. Mocarski, P. S. Moore, B. Roizman, R. Whitley, and K. Yamanishi (Cambridge: Cambridge University Press), 204-230.

Montag, C., Wagner, J. A., Gruska, I., Vetter, B., Wiebusch, L., and Hagemeier, C. (2011). The latency-associated UL138 gene product of human cytomegalovirus sensitizes cells to tumor necrosis factor alpha (TNF-alpha) signaling by upregulating TNF-alpha receptor 1 cell surface expression. J. Virol. 85, 11409-11421. doi: 10.1128/JVI.05028-11

Moorman, N. J., Cristea, I. M., Terhune, S. S., Rout, M. P., Chait, B. T., and Shenk, T. (2008). Human cytomegalovirus protein UL38 inhibits host cell stress responses by antagonizing the tuberous sclerosis protein complex. Cell Host Microbe 3, 253-262. doi: 10.1016/j.chom.2008.03.002

Mucke, K., Paulus, C., Bernhardt, K., Gerrer, K., Schon, K., Fink, A., et al. (2014). Human cytomegalovirus major immediate early 1 protein targets host chromosomes by docking to the acidic pocket on the nucleosome surface. J. Virol. 88, 1228-1248. doi: 10.1128/JVI.02606-13

Muller, S., Zocher, G., Steinle, A., and Stehle, T. (2010). Structure of the HCMV UL16-MICB complex elucidates select binding of a viral immunoevasin to diverse NKG2D ligands. PLoS Pathog. 6:e1000723. doi: 10.1371/journal.ppat. 1000723

Murphy, E. A., and Shenk, T. (2008). "Human cytomegalovirus Genome," in Human Cytomegalovirus, eds T. Shenk and M. F. Stinski (Heidelberg: Springer Berlin Heidelberg), 1-20.

Nevels, M., Paulus, C., and Shenk, T. (2004). Human cytomegalovirus immediateearly 1 protein facilitates viral replication by antagonizing histone deacetylation. Proc. Natl. Acad. Sci. U.S.A. 101, 17234-17239. doi: 10.1073/pnas. 0407933101

Nguyen, N. L., Loveland, A. N., and Gibson, W. (2008). Nuclear localization sequences in cytomegalovirus capsid assembly proteins (UL80 proteins) are required for virus production: inactivating NLS1, NLS2, or both affects replication to strikingly different extents. J. Virol. 82, 5381-5389. doi: 10.1128/JVI.02697-07

Noriega, V. M., Hesse, J., Gardner, T. J., Besold, K., Plachter, B., and Tortorella, D. (2012b). Human cytomegalovirus US3 modulates destruction of MHC class I molecules. Mol. Immunol. 51, 245-253. doi: 10.1016/j.molimm.2012.03.024

Noriega, V., Redmann, V., Gardner, T., and Tortorella, D. (2012a). Diverse immune evasion strategies by human cytomegalovirus. Immunol. Res. 54, 140-151. doi: $10.1007 / \mathrm{s} 12026-012-8304-8$

O'Connor, C. M., and Shenk, T. (2011). Human cytomegalovirus pUS27 G proteincoupled receptor homologue is required for efficient spread by the extracellular route but not for direct cell-to-cell spread. J. Virol. 85, 3700-3707. doi: 10.1128/JVI.02442-10

O'Connor, C. M., and Shenk, T. (2012). Human cytomegalovirus pUL78 G protein-coupled receptor homologue is required for timely cell entry in epithelial cells but not fibroblasts. J. Virol. 86, 11425-11433. doi: 10.1128/JVI. 05900-11

Odeberg, J., Browne, H., Metkar, S., Froelich, C. J., Branden, L., Cosman, D., et al. (2003). The human cytomegalovirus protein UL16 mediates increased resistance to natural killer cell cytotoxicity through resistance to cytolytic proteins. J. Virol. 77, 4539-4545. doi: 10.1128/JVI.77.8.4539-4545.2003

Omoto, S., and Mocarski, E. S. (2013). Transcription of true late (gamma2) cytomegalovirus genes requires betagamma-conserved UL92 function. J. Virol. 88, 120-130. doi: 10.1128/JVI.01052-13

Omoto, S., and Mocarski, E. S. (2014). Transcription of true late (gamma2) cytomegalovirus genes requires UL92 function that is conserved among beta- and gammaherpesviruses. J. Virol. 88, 120-130. doi: 10.1128/JVI. 02983-13

Oosten, L. E., Koppers-Lalic, D., Blokland, E., Mulder, A., Ressing, M. E., Mutis, T., et al. (2007). TAP-inhibiting proteins US6, ICP47 and UL49.5 differentially affect minor and major histocompatibility antigen-specific recognition by cytotoxic $\mathrm{T}$ lymphocytes. Int. Immunol. 19, 1115-1122. doi: 10.1093/intimm/dxm082

Oresic, K., Noriega, V., Andrews, L., and Tortorella, D. (2006). A structural determinant of human cytomegalovirus US2 dictates the down-regulation of class I major histocompatibility molecules. J. Biol. Chem. 281, 19395-19406. doi: 10.1074/jbc.M601026200

Oresic, K., and Tortorella, D. (2008). Endoplasmic reticulum chaperones participate in human cytomegalovirus US2-mediated degradation of class I major histocompatibility complex molecules. J. Gen. Virol. 89, 1122-1130. doi: 10.1099/vir.0.83516-0

Park, B., Spooner, E., Houser, B. L., Strominger, J. L., and Ploegh, H. L. (2010). The HCMV membrane glycoprotein US10 selectively targets HLA-G for degradation. J. Exp. Med. 207, 2033-2041. doi: 10.1084/jem.20091793

Pass, R. F., Fowler, K. B., Boppana, S. B., Britt, W. J., and Stagno, S. (2006). Congenital cytomegalovirus infection following first trimester maternal infection: symptoms at birth and outcome. J. Clin. Virol. 35, 216-220. doi: 10.1016/j.jcv.2005.09.015

Patrone, M., Percivalle, E., Secchi, M., Fiorina, L., Pedrali-Noy, G., Zoppe, M., et al. (2003). The human cytomegalovirus UL45 gene product is a late, virionassociated protein and influences virus growth at low multiplicities of infection. J. Gen. Virol. 84, 3359-3370. doi: 10.1099/vir.0.19452-0

Patrone, M., Secchi, M., Fiorina, L., Ierardi, M., Milanesi, G., and Gallina, A. (2005). Human cytomegalovirus UL130 protein promotes endothelial cell infection through a producer cell modification of the virion. J. Virol. 79, 8361-8373. doi: 10.1128/JVI.79.13.8361-8373.2005

Paulus, C., Krauss, S., and Nevels, M. (2006). A human cytomegalovirus antagonist of type I IFN-dependent signal transducer and activator of transcription signaling. Proc. Natl. Acad. Sci. U.S.A. 103, 3840-3845. doi: 10.1073/pnas.0600007103

Penkert, R. R., and Kalejta, R. F. (2012). Tale of a tegument transactivator: the past, present and future of human CMV pp71. Future Virol. 7, 855-869. doi: $10.2217 / \mathrm{fvl} .12 .86$

Pereira, L., Maidji, E., Tugizov, S., and Jones, T. (1995). Deletion mutants in human cytomegalovirus glycoprotein US9 are impaired in cell-cell transmission and in altering tight junctions of polarized human retinal pigment epithelial cells. Scand. J. Infect. Dis. Suppl. 99, 82-87.

Perng, Y. C., Qian, Z., Fehr, A. R., Xuan, B., and Yu, D. (2011). The human cytomegalovirus gene UL79 is required for the accumulation of late viral transcripts. J. Virol. 85, 4841-4852. doi: 10.1128/JVI.02344-10 
Petrucelli, A., Rak, M., Grainger, L., and Goodrum, F. (2009). Characterization of a novel Golgi apparatus-localized latency determinant encoded by human cytomegalovirus. J. Virol. 83, 5615-5629. doi: 10.1128/JVI.01989-08

Phillips, S. L., and Bresnahan, W. A. (2012). The human cytomegalovirus (HCMV) tegument protein UL94 is essential for secondary envelopment of HCMV virions. J. Virol. 86, 2523-2532. doi: 10.1128/JVI.06548-11

Phillips, S. L., Cygnar, D., Thomas, A., and Bresnahan, W. A. (2012). Interaction between the human cytomegalovirus tegument proteins UL94 and UL99 is essential for virus replication. J. Virol. 86, 9995-10005. doi: 10.1128/JVI. 01078-12

Poole, E., Atkins, E., Nakayama, T., Yoshie, O., Groves, I., Alcami, A., et al. (2008). NF-kappaB-mediated activation of the chemokine CCL22 by the product of the human cytomegalovirus gene UL144 escapes regulation by viral IE86. J. Virol. 82, 4250-4256. doi: 10.1128/JVI.02156-07

Poole, E., King, C. A., Sinclair, J. H., and Alcami, A. (2006). The UL144 gene product of human cytomegalovirus activates NFkappaB via a TRAF6-dependent mechanism. EMBO J. 25, 4390-4399. doi: 10.1038/sj.emboj.7601287

Poole, E., Walther, A., Raven, K., Benedict, C. A., Mason, G. M., and Sinclair, J. (2013). The myeloid transcription factor GATA-2 regulates the viral UL144 gene during human cytomegalovirus latency in an isolate-specific manner. J. Virol. 87, 4261-4271. doi: 10.1128/JVI.03497-12

Prichard, M. N., Duke, G. M., and Mocarski, E. S. (1996). Human cytomegalovirus uracil DNA glycosylase is required for the normal temporal regulation of both DNA synthesis and viral replication. J. Virol. 70, 3018-3025.

Prod'homme, V., Sugrue, D. M., Stanton, R. J., Nomoto, A., Davies, J., Rickards, C. R., et al. (2010). Human cytomegalovirus UL141 promotes efficient downregulation of the natural killer cell activating ligand CD112. J. Gen. Virol. 91, 2034-2039. doi: 10.1099/vir.0.021931-0

Qi, Y., Mao, Z. Q., Ruan, Q., He, R., Ma, Y. P., Sun, Z. R., et al. (2006). Human cytomegalovirus (HCMV) UL139 open reading frame: Sequence variants are clustered into three major genotypes. J. Med. Virol. 78, 517-522. doi: 10.1002/jmv.20571

Qian, Z., Xuan, B., Gualberto, N., and Yu, D. (2011). The human cytomegalovirus protein pUL38 suppresses endoplasmic reticulum stress-mediated cell death independently of its ability to induce mTORC1 activation. J. Virol. 85, 9103-9113. doi: 10.1128/JVI.00572-11

Qian, Z., Xuan, B., Hong, T. T., and Yu, D. (2008). The full-length protein encoded by human cytomegalovirus gene UL117 is required for the proper maturation of viral replication compartments. J. Virol. 82, 3452-3465. doi: 10.1128/JVI. 01964-07

Raftery, M. J., Moncke-Buchner, E., Matsumura, H., Giese, T., Winkelmann, A., Reuter, M., et al. (2009). Unravelling the interaction of human cytomegalovirus with dendritic cells by using SuperSAGE. J. Gen. Virol. 90, 2221-2233. doi: 10.1099/vir.0.010538-0

Ranneberg-Nilsen, T., Dale, H. A., Luna, L., Slettebakk, R., Sundheim, O., Rollag, H., et al. (2008). Characterization of human cytomegalovirus uracil DNA glycosylase (UL114) and its interaction with polymerase processivity factor (UL44). J. Mol. Biol. 381, 276-288. doi: 10.1016/j.jmb.2008.05.028

Reeves, M. B. (2011). Chromatin-mediated regulation of cytomegalovirus gene expression. Virus Res. 157, 134-143. doi: 10.1016/j.virusres.2010.09.019

Reeves, M. B., Davies, A. A., McSharry, B. P., Wilkinson, G. W., and Sinclair, J. H. (2007). Complex I binding by a virally encoded RNA regulates mitochondriainduced cell death. Science 316, 1345-1348. doi: 10.1126/science.1142984

Reeves, M. B., Lehner, P. J., Sissons, J. G., and Sinclair, J. H. (2005). An in vitro model for the regulation of human cytomegalovirus latency and reactivation in dendritic cells by chromatin remodelling. J. Gen. Virol. 86, 2949-2954. doi: 10.1099/vir.0.81161-0

Reeves, M. B., and Sinclair, J. H. (2009). Analysis of latent viral gene expression in natural and experimental latency models of human cytomegalovirus and its correlation with histone modifications at a latent promoter. J. Gen. Virol. 91, 599-604. doi: 10.1099/vir.0.015602-0

Reitsma, J. M., Sato, H., Nevels, M., Terhune, S. S., and Paulus, C. (2013). Human cytomegalovirus IE1 protein disrupts interleukin-6 signaling by sequestering STAT3 in the nucleus. J. Virol. 87, 10763-10776. doi: 10.1128/JVI.01197-13

Revilleza, M. J., Wang, R., Mans, J., Hong, M., Natarajan, K., and Margulies, D. H. (2011). How the virus outsmarts the host: function and structure of cytomegalovirus MHC-I-like molecules in the evasion of natural killer cell surveillance. J. Biomed. Biotechnol. 2011:724607. doi: 10.1155/2011/ 724607
Rossetto, C. C., Tarrant-Elorza, M., and Pari, G. S. (2013). Cis and trans acting factors involved in human cytomegalovirus experimental and natural latent infection of CD14 (+) monocytes and CD34 (+) Cells. PLoS Pathog. 9:e1003366. doi: 10.1371/journal.ppat.1003366

Ryckman, B. J., Chase, M. C., and Johnson, D. C. (2008). HCMV gH/gL/UL128131 interferes with virus entry into epithelial cells: evidence for cell typespecific receptors. Proc. Natl. Acad. Sci. U.S.A. 105, 14118-14123. doi: 10.1073/pnas.0804365105

Salsman, J., Jagannathan, M., Paladino, P., Chan, P. K., Dellaire, G., Raught, B., et al. (2012). Proteomic profiling of the human cytomegalovirus UL35 gene products reveals a role for UL35 in the DNA repair response. J. Virol. 86, 806-820. doi: 10.1128/JVI.05442-11

Savaryn, J. P., Reitsma, J. M., Bigley, T. M., Halligan, B. D., Qian, Z., Yu, D., et al. (2013). Human cytomegalovirus pUL29/28 and pUL38 repression of p53-regulated p21CIP1 and caspase 1 promoters during infection. J. Virol. 87, 2463-2474. doi: 10.1128/JVI.01926-12

Schauflinger, M., Fischer, D., Schreiber, A., Chevillotte, M., Walther, P., Mertens, T., et al. (2011). The tegument protein UL71 of human cytomegalovirus is involved in late envelopment and affects multivesicular bodies. J. Virol. 85, 3821-3832. doi: 10.1128/JVI.01540-10

Schuessler, A., Sampaio, K. L., and Sinzger, C. (2008). Charge cluster-toalanine scanning of UL128 for fine tuning of the endothelial cell tropism of human cytomegalovirus. J. Virol. 82, 11239-11246. doi: 10.1128/JVI. 01069-08

Schuessler, A., Sampaio, K. L., Straschewski, S., and Sinzger, C. (2012). Mutational mapping of pUL131A of human cytomegalovirus emphasizes its central role for endothelial cell tropism. J. Virol. 86, 504-512. doi: 10.1128/JVI.05354-11

Sharma, M., Kamil, J. P., Coughlin, M., Reim, N. I., and Coen, D. M. (2014). Human cytomegalovirus UL50 and UL53 recruit viral protein kinase UL97, not protein kinase $\mathrm{C}$, for disruption of nuclear lamina and nuclear egress in infected cells. J. Virol. 88, 249-262. doi: 10.1128/JVI.02358-13

Shikhagaie, M., Merce-Maldonado, E., Isern, E., Muntasell, A., Alba, M. M., LopezBotet, M., et al. (2012). The human cytomegalovirus-specific UL1 gene encodes a late-phase glycoprotein incorporated in the virion envelope. J. Virol. 86, 4091-4101. doi: 10.1128/JVI.06291-11

Siew, V. K., Duh, C. Y., and Wang, S. K. (2009). Human cytomegalovirus UL76 induces chromosome aberrations. J. Biomed. Sci. 16, 107. doi: 10.1186/14230127-16-107

Silva, M. C., Yu, Q. C., Enquist, L., and Shenk, T. (2003). Human cytomegalovirus UL99-encoded pp28 is required for the cytoplasmic envelopment of tegumentassociated capsids. J. Virol. 77, 10594-10605. doi: 10.1128/JVI.77.19.1059410605.2003

Sindre, H., Tjoonnfjord, G. E., Rollag, H., Ranneberg-Nilsen, T., Veiby, O. P., Beck, S., et al. (1996). Human cytomegalovirus suppression of and latency in early hematopoietic progenitor cells. Blood 88, 4526-4533.

Sinzger, C., Bissinger, A. L., Viebahn, R., Oettle, H., Radke, C., Schmidt, C. A., et al. (1999). Hepatocytes are permissive for human cytomegalovirus infection in human liver cell culture and In vivo. J. Infect. Dis. 180, 976-986. doi: $10.1086 / 315032$

Slinger, E., Maussang, D., Schreiber, A., Siderius, M., Rahbar, A., Fraile-Ramos, A., et al. (2010). HCMV-encoded chemokine receptor US28 mediates proliferative signaling through the IL-6-STAT3 axis. Sci. Signal. 3, ra58. doi: 10.1126/scisignal.2001180

Smith, J. A., and Pari, G. S. (1995a). Expression of human cytomegalovirus UL36 and UL37 genes is required for viral DNA replication. J. Virol. 69, 1925-1931.

Smith, J. A., and Pari, G. S. (1995b). Human cytomegalovirus UL102 gene. J. Virol. 69, 1734-1740.

Smith, W., Tomasec, P., Aicheler, R., Loewendorf, A., Nemcovicova, I., Wang, E. C., et al. (2013). Human cytomegalovirus glycoprotein UL141 targets the TRAIL death receptors to thwart host innate antiviral defenses. Cell Host Microbe 13, 324-335. doi: 10.1016/j.chom.2013.02.003

Smuda, C., Bogner, E., and Radsak, K. (1997). The human cytomegalovirus glycoprotein B gene (ORF UL55) is expressed early in the infectious cycle. J. Gen. Virol. 78(Pt 8), 1981-1992.

Soderberg-Naucler, C., Fish, K. N., and Nelson, J. A. (1997). Reactivation of latent human cytomegalovirus by allogeneic stimulation of blood cells from healthy donors. Cell 91, 119-126. doi: 10.1016/S0092-8674(01)80014-3

Soderberg-Naucler, C., Streblow, D. N., Fish, K. N., Allan-Yorke, J., Smith, P. P., and Nelson, J. A. (2001). Reactivation of latent human cytomegalovirus in 
CD14(+) monocytes is differentiation dependent. J. Virol. 75, 7543-7554. doi: 10.1128/JVI.75.16.7543-7554.2001

Spaderna, S., Kropff, B., Kodel, Y., Shen, S., Coley, S., Lu, S., et al. (2005). Deletion of gpUL132, a structural component of human cytomegalovirus, results in impaired virus replication in fibroblasts. J. Virol. 79, 11837-11847. doi: 10.1128/JVI.79.18.11837-11847.2005

Stamminger, T., Gstaiger, M., Weinzierl, K., Lorz, K., Winkler, M., and Schaffner, W. (2002). Open reading frame UL26 of human cytomegalovirus encodes a novel tegument protein that contains a strong transcriptional activation domain. J. Virol. 76, 4836-4847. doi: 10.1128/JVI.76.10.4836-4847.2002

Stanton, R. J., Baluchova, K., Dargan, D. J., Cunningham, C., Sheehy, O., Seirafian, S., et al. (2010). Reconstruction of the complete human cytomegalovirus genome in a BAC reveals RL13 to be a potent inhibitor of replication. J. Clin. Invest. 120, 3191-3208. doi: 10.1172/JCI42955

Stenberg, R. M., Witte, P. R., and Stinski, M. F. (1985). Multiple spliced and unspliced transcripts from human cytomegalovirus immediate-early region 2 and evidence for a common initiation site within immediate-early region 1 . J. Virol. 56, 665-675.

Stern-Ginossar, N., Weisburd, B., Michalski, A., Le, V. T., Hein, M. Y., Huang, S. X., et al. (2012). Decoding human cytomegalovirus. Science 338, 1088-1093. doi: $10.1126 /$ science. 1227919

Stinski, M. F., and Meier, J. L. (2007). "Immediate-early viral gene regulation and function," in Human Herpesviruses: Biology, Therapy, and Immunoprophylaxis, eds A. Arvin, G. Campadelli-Fiume, E. Mocarski, P.S. Moore, B. Roizman, R. Whitley, and K. Yamanishi (Cambridge: Cambridge University Press), 241-263.

Stinski, M. F., Thomsen, D. R., Stenberg, R. M., and Goldstein, L. C. (1983). Organization and expression of the immediate early genes of human cytomegalovirus. J. Virol. 46, 1-14.

Strang, B. L., Bender, B. J., Sharma, M., Pesola, J. M., Sanders, R. L., Spector, D. H., et al. (2012). A mutation deleting sequences encoding the amino terminus of human cytomegalovirus UL84 impairs interaction with UL44 and capsid localization. J. Virol. 86, 11066-11077. doi: 10.1128/JVI.01379-12

Strang, B. L., and Coen, D. M. (2010). Interaction of the human cytomegalovirus uracil DNA glycosylase UL114 with the viral DNA polymerase catalytic subunit UL54. J. Gen. Virol. 91, 2029-2033. doi: 10.1099/vir.0.022160-0

Strang, B. L., Geballe, A. P., and Coen, D. M. (2010). Association of human cytomegalovirus proteins IRS1 and TRS1 with the viral DNA polymerase accessory subunit UL44. J. Gen. Virol. 91, 2167-2175. doi: 10.1099/vir.0. 022640-0

Straschewski, S., Patrone, M., Walther, P., Gallina, A., Mertens, T., and Frascaroli, G. (2011). Protein pUL128 of human cytomegalovirus is necessary for monocyte infection and blocking of migration. J. Virol. 85, 5150-5158. doi: 10.1128/JVI.02100-10

Stropes, M. P., Schneider, O. D., Zagorski, W. A., Miller, J. L., and Miller, W. E. (2009). The carboxy-terminal tail of human cytomegalovirus (HCMV) US28 regulates both chemokine-independent and chemokine-dependent signaling in HCMV-infected cells. J. Virol. 83, 10016-10027. doi: 10.1128/JVI. 00354-09

Tadagaki, K., Tudor, D., Gbahou, F., Tschische, P., Waldhoer, M., Bomsel, M., et al. (2012). Human cytomegalovirus-encoded UL33 and UL78 heteromerize with host CCR5 and CXCR4 impairing their HIV coreceptor activity. Blood 119, 4908-4918. doi: 10.1182/blood-2011-08-372516

Tandon, R., and Mocarski, E. S. (2011). Cytomegalovirus pUL96 is critical for the stability of pp150-associated nucleocapsids. J. Virol. 85, 7129-7141. doi: 10.1128/JVI.02549-10

Tandon, R., and Mocarski, E. S. (2012). Viral and host control of cytomegalovirus maturation. Trends Microbiol. 20, 392-401. doi: 10.1016/j.tim.2012.04.008

Taylor-Wiedeman, J., Sissons, J. G., Borysiewicz, L. K., and Sinclair, J. H. (1991). Monocytes are a major site of persistence of human cytomegalovirus in peripheral blood mononuclear cells. J. Gen. Virol. 72(Pt 9), 2059-2064. doi: 10.1099/0022-1317-72-9-2059

Terhune, S. S., Moorman, N. J., Cristea, I. M., Savaryn, J. P., Cuevas-Bennett, C., Rout, M. P., et al. (2010). Human cytomegalovirus UL29/28 protein interacts with components of the NuRD complex which promote accumulation of immediate-early RNA. PLoS Pathog. 6:e1000965. doi: 10.1371/journal.ppat.1000965

Terhune, S., Torigoi, E., Moorman, N., Silva, M., Qian, Z., Shenk, T., et al. (2007). Human cytomegalovirus UL38 protein blocks apoptosis. J. Virol. 81, 3109-3123. doi: 10.1128/JVI.02124-06
Thoma, C., and Bogner, E. (2010). Short hairpin RNAs specific to human cytomegalovirus terminase subunit pUL89 prevent viral maturation. Antivir. Ther. 15, 391-400. doi: 10.3851/IMP1536

Tirabassi, R., Hook, L., Landais, I., Grey, F., Meyers, H., Hewitt, H., et al. (2011). Human cytomegalovirus US7 is regulated synergistically by two virally encoded microRNAs and by two distinct mechanisms. J. Virol. 85, 11938-11944. doi: 10.1128/JVI.05443-11

Tomtishen, J. P. 3rd. (2012). Human cytomegalovirus tegument proteins (pp65, pp71, pp150, pp28). Virol. J. 9, 22. doi: 10.1186/1743-422X-9-22

Vieira, J., Schall, T. J., Corey, L., and Geballe, A. P. (1998). Functional analysis of the human cytomegalovirus US28 gene by insertion mutagenesis with the green fluorescent protein gene. J. Virol. 72, 8158-8165.

Vitale, M., Castriconi, R., Parolini, S., Pende, D., Hsu, M. L., Moretta, L., et al. (1999). The leukocyte Ig-like receptor (LIR)-1 for the cytomegalovirus UL18 protein displays a broad specificity for different HLA class I alleles: analysis of LIR-1 + NK cell clones. Int. Immunol. 11, 29-35. doi: 10.1093/intimm/11.1.29

Wang, D., and Shenk, T. (2005). Human cytomegalovirus UL131 open reading frame is required for epithelial cell tropism. J. Virol. 79, 10330-10338. doi: 10.1128/JVI.79.16.10330-10338.2005

Wang, K., Li, Y., Zhao, G., Wu, Y., Zhang, X., Li, H., et al. (2013a). Inhibition of human cytomegalovirus DNA replication by small interfering RNAs targeted to UL49. Acta Biochim. Biophys. Sin. (Shanghai). 45, 401-407. doi: 10.1093/abbs/gmt025

Wang, N., Ma, Y., Li, M., Gao, S., Wang, L., Qi, Y., et al. (2013b). Transcription characteristics of the human cytomegalovirus UL13 gene. Arch. Virol. 158, 473-477. doi: 10.1007/s00705-012-1461-1

Wang, N., Ma, Y., Sun, Z., Qi, Y., Ji, Y., He, R., et al. (2011). Transcriptional features and transcript structure of UL145 in different strains of human cytomegalovirus. J. Med. Virol. 83, 2151-2156. doi: 10.1002/jmv.22241

Wang, S. K., Duh, C. Y., and Wu, C. W. (2004). Human cytomegalovirus UL76 encodes a novel virion-associated protein that is able to inhibit viral replication. J. Virol. 78, 9750-9762. doi: 10.1128/JVI.78.18.9750-9762.2004

Wathen, M. W., and Stinski, M. F. (1982). Temporal patterns of human cytomegalovirus transcription: mapping the viral RNAs synthesized at immediate early, early, and late times after infection. J. Virol. 41, 462-477.

Welch, A. R., McNally, L. M., and Gibson, W. (1991). Cytomegalovirus assembly protein nested gene family: four 3'-coterminal transcripts encode four in-frame, overlapping proteins. J. Virol. 65, 4091-4100.

Wen, D. Q., Zhang, Y. Y., Lv, L. P., Zhou, X. P., Yan, F., Ma, P., et al. (2009). Human cytomegalovirus-encoded chemokine receptor homolog US28 stimulates the major immediate early gene promoter/enhancer via the induction of CREB. J. Recept. Signal Transduct. Res. 29, 266-273. doi: 10.1080/10799890903178141

Wiertz, E. J., Jones, T. R., Sun, L., Bogyo, M., Geuze, H. J., and Ploegh, H. L. (1996). The human cytomegalovirus US11 gene product dislocates MHC class I heavy chains from the endoplasmic reticulum to the cytosol. Cell 84, 769-779. doi: 10.1016/S0092-8674(00)81054-5

Wills, M. R., Ashiru, O., Reeves, M. B., Okecha, G., Trowsdale, J., Tomasec, P., et al. (2005). Human cytomegalovirus encodes an MHC class I-like molecule (UL142) that functions to inhibit NK cell lysis. J. Immunol. 175, 7457-7465. doi: 10.4049/jimmunol.175.11.7457

Wing, B. A., and Huang, E. S. (1995). Analysis and mapping of a family of 3'coterminal transcripts containing coding sequences for human cytomegalovirus open reading frames UL93 through UL99. J. Virol. 69, 1521-1531.

Wing, B. A., Lee, G. C., and Huang, E. S. (1996). The human cytomegalovirus UL94 open reading frame encodes a conserved herpesvirus capsid/tegumentassociated virion protein that is expressed with true late kinetics. J. Virol. 70, 3339-3345.

Winkler, M., Rice, S. A., and Stamminger, T. (1994). UL69 of human cytomegalovirus, an open reading frame with homology to ICP27 of herpes simplex virus, encodes a transactivator of gene expression. J. Virol. 68, 3943-3954.

Womack, A. W. (2011). Genetic Dissection of Virion Maturation and Epithelial Cell Tropism in Human Cytomegalovirus. Princeton: Princeton University.

Woon, H. G., Scott, G. M., Yiu, K. L., Miles, D. H., and Rawlinson, W. D. (2008). Identification of putative functional motifs in viral proteins essential for human cytomegalovirus DNA replication. Virus Genes 37, 193-202. doi: 10.1007/s11262-008-0255-8

Wu, T. C., Lee, W. A., Pizzorno, M. C., Au, W. C., Chan, Y. J., Hruban, R. H., et al. (1992). Localization of the human cytomegalovirus 2.7-kb major 
early beta-gene transcripts by RNA in situ hybridization in permissive and nonpermissive infections. Am. J. Pathol. 141, 1247-1254.

Wyrwicz, L. S., and Rychlewski, L. (2008). Cytomegalovirus immediate early gene UL37 encodes a novel MHC-like protein. Acta Biochim. Pol. 55, 67-73.

Xiaofei, E., Stadler, B. M., Debatis, M., Wang, S., Lu, S., and Kowalik, T. F. (2012). RNA interference-mediated targeting of human cytomegalovirus immediateearly or early gene products inhibits viral replication with differential effects on cellular functions. J. Virol. 86, 5660-5673. doi: 10.1128/JVI.06338-11

Xuan, B., Qian, Z., Torigoi, E., and Yu, D. (2009). Human cytomegalovirus protein pUL38 induces ATF4 expression, inhibits persistent JNK phosphorylation, and suppresses endoplasmic reticulum stress-induced cell death. J. Virol. 83, 3463-3474. doi: 10.1128/JVI.02307-08

Yu, D., Silva, M. C., and Shenk, T. (2003). Functional map of human cytomegalovirus AD169 defined by global mutational analysis. Proc. Natl. Acad. Sci. U.S.A. 100, 12396-12401. doi: 10.1073/pnas.1635160100

Zalckvar, E., Paulus, C., Tillo, D., Asbach-Nitzsche, A., Lubling, Y., Winterling, C., et al. (2013). Nucleosome maps of the human cytomegalovirus genome reveal a temporal switch in chromatin organization linked to a major IE protein. Proc. Natl. Acad. Sci. U.S.A. 110, 13126-13131. doi: 10.1073/pnas.1305548110

Zhang, G., Raghavan, B., Kotur, M., Cheatham, J., Sedmak, D., Cook, C., et al. (2007). Antisense transcription in the human cytomegalovirus transcriptome. J. Virol. 81, 11267-11281 doi: 10.1128/JVI.00007-07

Zhang, W., Li, H., Li, Y., Zeng, Z., Li, S., Zhang, X., et al. (2010). Effective inhibition of HCMV UL49 gene expression and viral replication by oligonucleotide external guide sequences and RNase P. Virol. J. 7, 100. doi: 10.1186/1743-42 2X-7-100
Zheng, Q., Tao, R., Gao, H., Xu, J., Shang, S., and Zhao, N. (2012). HCMV-encoded UL128 enhances TNF-alpha and IL-6 expression and promotes PBMC proliferation through the MAPK/ERK pathway in vitro. Viral Immunol. 25, 98-105. doi: 10.1089/vim.2011.0064

Zhuravskaya, T., Maciejewski, J. P., Netski, D. M., Bruening, E., Mackintosh, F. R., and St Jeor, S. (1997). Spread of human cytomegalovirus (HCMV) after infection of human hematopoietic progenitor cells: model of HCMV latency. Blood 90, 2482-2491.

Conflict of Interest Statement: The authors declare that the research was conducted in the absence of any commercial or financial relationships that could be construed as a potential conflict of interest.

Received: 04 February 2014; accepted: 25 April 2014; published online: 19 May 2014. Citation: Van Damme E and Van Loock M (2014) Functional annotation of human cytomegalovirus gene products: an update. Front. Microbiol. 5:218. doi: 10.3389/ fmicb.2014.00218

This article was submitted to Virology, a section of the journal Frontiers in Microbiology.

Copyright (c) 2014 Van Damme and Van Loock. This is an open-access article distributed under the terms of the Creative Commons Attribution License (CC BY). The use, distribution or reproduction in other forums is permitted, provided the original author(s) or licensor are credited and that the original publication in this journal is cited, in accordance with accepted academic practice. No use, distribution or reproduction is permitted which does not comply with these terms. 